\title{
Guaraná (Paullinia cupana Kunth) effects on LDL oxidation in elderly people: an in vitro and in vivo study
}

Rafael de Lima Portella', Rômulo Pillon Barcelos ${ }^{1}$, Edovando José Flores da Rosa ${ }^{1}$, Euler Esteves Ribeiro², Ivana Beatrice Mânica da Cruz ${ }^{1,2,3}$, Leila Suleiman ${ }^{1}$ and Felix Alexandre Antunes Soares ${ }^{1 *}$

\begin{abstract}
Background: Previous experimental investigations have suggested that guaraná (Paullinia cupana Kunth, supplied by EMBRAPA Oriental) consumption is associated with a lower prevalence of cardiovascular metabolic diseases and has positive effects on lipid metabolism, mainly related to low density lipoprotein (LDL) levels. As LDL oxidation is an important initial event in the development of atherosclerosis, we performed in vitro and in vivo studies to observe the potential effects of guaraná on LDL and serum oxidation.

Methods: The in vivo protocol was performed using blood samples from 42 healthy elderly subjects who habitually ingested guaraná (GI) or never ingested guaraná (NG). The formation of conjugated dienes (CDs) was analyzed from serum samples. The in vitro protocols were performed using LDL obtained from 3 healthy, non-fasted, normolipidemic voluntary donors who did not habitually ingest guaraná in their diets. The LDL samples were exposed to 5 different guaraná concentrations $(0.05,0.1,0.5,1$, and $5 \mu \mathrm{g} / \mathrm{mL})$.

Results: Gl subjects demonstrated lower LDL oxidation than did NG subjects (reduction of $27 \%, p<0.0014$ ), independent of other variables. In the Gl group the total polyphenols was positively associated with LDL levels. Also, guaraná demonstrated a high antioxidant activity in vitro, mainly at concentrations of 1 and $5 \mu \mathrm{g} / \mathrm{mL}$, demonstrated by suppression of CDs and TBARS productions, tryptophan destruction and high TRAP activity.
\end{abstract}

Conclusions: Guaraná, similar to other foods rich in caffeine and catechins such as green tea, has some effect on LDL oxidation that could partially explain the protective effects of this food in cardiometabolic diseases.

Keywords: Lipoperoxidation, Humans, Antioxidant, Plant extract

\section{Background}

Foods rich in catechins and caffeine, such as tea and coffee, are the most popular beverages in the world, and have been consumed for thousands of years because of their alluring flavors and health benefits. Several epidemiological and experimental investigations have described an inverse association between tea consumption and cardiovascular diseases [1]. A recent study described an association between coffee and tea consumption and a low morbidity and mortality risk from stroke, coronary heart disease (CHD), and all causes of mortality in 37,514

\footnotetext{
* Correspondence: felix@ufsm.br

'Departamento de Química, Centro de Ciências Naturais e Exatas,

Universidade Federal de Santa Maria, Campus UFSM, Santa Maria, RS, Brazil Full list of author information is available at the end of the article
}

subjects followed for 13 years [2]. A possible causal factor associated with tea and coffee consumption is the role of bioactive compounds present in these foods in metabolic pathways related to body weight loss, and a consequent reduction of the overall risk for developing metabolic syndrome [3].

However, it is important to analyze whether other foods rich in these compounds show biological properties similar to those of the guaraná used in energy drinks (Paullinia cupana H.B.K., Sapindaceae) [4]. Guaraná is a rainforest vine that was domesticated in the Amazon for its caffeine-rich fruits. During the last two decades, guaraná has emerged as a key ingredient in various 'sports' and energy drinks [5]. Energy drinks have increased in popularity with adolescents and young adults. Caffeine,

\section{Biomed Central}

(c) 2013 Portella et al.; licensee BioMed Central Ltd. This is an Open Access article distributed under the terms of the Creative Commons Attribution License (http://creativecommons.org/licenses/by/2.0), which permits unrestricted use, distribution, and reproduction in any medium, provided the original work is properly cited. 
the most physiologically active ingredient in energy drinks, is generally considered safe by the US Food and Drug Administration (FDA), although adverse effects can occur at varying amounts. Guaraná, which contains caffeine in addition to small amounts of theobromine, theophylline, and tannins, is also recognized as safe by the FDA [6]. Because the consumption of guaraná is growing in many countries, studies on its functional properties are needed.

Previous experimental investigations have suggested that guaraná has positive effects on lipid metabolism [7], in body weight loss [8], and increases basal energy expenditure [9]. Furthermore, studies suggested that guaraná exhibits a cardioprotective effect by inhibiting platelet aggregation [10]. These all positive effects contributed to reduce the risk factors for cardiovascular diseases. However, in contrast to green tea and coffee, on which many epidemiological studies have been performed, investigations involving guaraná consumption are difficult to perform because guaraná originates in a specific Brazilian Amazonian region (Maués-AM) [5]. Besides, there is no information whether guaraná consumption might increase the resistance to low density lipoprotein (LDL) oxidation.

For this reason, a controlled study was recently performed to analyze the association between habitual guaraná consumption and the prevalence of metabolic disease (obesity, hypertension, type 2 diabetes, and dyslipidemia) in an elderly population living in the Amazon's Riverine region (Maués-AM). The study observed a lower prevalence of hypertension, obesity, and metabolic syndrome in the subjects which self-reported habitual guaraná consumption (GI) than in subjects who reported never ingesting guaraná (NG). Additionally an association was found between habitual guaraná consumption and lower cholesterol (total and LDL) and advanced oxidative protein product (AOPP) levels [11]. The potential effect of guaraná on LDL levels as well as oxidative biomarkers (AOPP) could provide a possible causal explanation for the lower prevalence of some cardiovascular metabolic diseases observed in Maués's study.

These results lead us to verify whether guaraná may have a possible antiatherogenic activity. Lipid peroxidation induced by free radicals has been implicated in the pathogenesis of various diseases. Numerous in vitro and animal studies have shown that oxidative modification of LDL is an important initial event for the development of atherosclerosis [12]. Moreover, it is known that age is one of the major risk factor for atherosclerotic vascular disease [13]. Plasma cholesterol, triglyceride, LDL, polyunsaturated fatty acid (PUFA), total fatty acid and malondialdehyde levels, were found to increase in aged humans compared with young groups [14]. In addition, VLDL + LDL oxidizability increased and total thiol content levels in plasma decreased in aged humans and rats compared with young groups [14].
The experimental studies described earlier and the established inverse relationship between the consumption of fruit and vegetables and cardiovascular diseases have led to a number of new studies on patients and populations that, for the most part, seem to reinforce the central role of antioxidants as protective nutrients [13]. Considering these facts, we performed an in vivo study to investigate the potential effects of guaraná in elderly people on serum oxidation and an in vitro study in order to investigate the antioxidant effects of guaraná on the LDL and serum oxidation.

\section{Results}

\section{Baseline characteristics of subjects}

The baseline characteristics of GI and NG elderly subjects included in the in vivo serum oxidation assay are presented in Table 1. In general, the two elderly groups were similar in BMI, blood pressure, glucose levels, and certain lipid parameters. However, the levels of total cholesterol were higher in the NG subjects than in the GI subjects. Additionally, the oxidative biomarker parameters such as TBARS, total polyphenols, and protein carbonylation were similar for the two groups.

\section{Conjugated diene levels in Maués's population}

The serum samples from elderly GI and NG subjects were evaluated for maximum $C D$ production. The diene levels were significantly different between the two groups analyzed here. The GI group showed lower diene formation (reduction of $27 \%, \mathrm{p}<0.0014$ ) than the NG group

Table 1 Parameters from people who habitually ingest guaraná (GI) and those who never ingest guaraná (NG)

\begin{tabular}{llll}
\hline Variables & Gl & NG & $\boldsymbol{p}$ \\
& Means \pm SD & Means \pm SD & \\
\hline Age (years) & $73.6 \pm 6.5$ & $75.2 \pm 9.4$ & 0.56 \\
BMI (Kg/m $\left.{ }^{2}\right)$ & $27.4 \pm 3.3$ & $27.0 \pm 4.2$ & 0.58 \\
Waist circumference $(\mathrm{cm})$ & $87.6 \pm 11.1$ & $82.5 \pm 10.9$ & 0.14 \\
SBP (mmHg) & $126.1 \pm 15.9$ & $130.0 \pm 15.8$ & 0.44 \\
DBP (mmHg) & $73.51 \pm 8.3$ & $76.51 \pm 4.9$ & 0.19 \\
Glucose (mg/dL) & $103.7 \pm 12.8$ & $108.6 \pm 14.1$ & 0.21 \\
Cholesterol total (mg/dL) & $189.7 \pm 30.8$ & $230.2 \pm 61.6$ & 0.009 \\
Triglycerides (mg/dL) & $128.7 \pm 47.7$ & $150.9 \pm 51.7$ & 0.57 \\
LDL (mg/dL) & $132.5 \pm 45.8$ & $161.1 \pm 52.6$ & 0.08 \\
HDL (mg/dL) & $42.6 \pm 24.0$ & $42.2 \pm 19.1$ & 0.96 \\
Uric acid (mg/dL) & $4.2 \pm 1.9$ & $5.4 \pm 2.9$ & 0.16 \\
TBARS & $21.7 \pm 7.9$ & $19.9 \pm 7.0$ & 0.44 \\
Protein carbonilation & $0.17 \pm 0.09$ & $0.14 \pm 0.07$ & 0.25 \\
Total polyphenols & $2.7 \pm 0.8$ & $2.7 \pm 0.5$ & 0.98 \\
\hline
\end{tabular}

$\mathrm{SD}=$ standard deviation; $\mathrm{BMI}=$ Body mass index $\left(\mathrm{Kg} / \mathrm{m}^{2}\right) ; \mathrm{SBP}=$ systolic blood pressure; $\mathrm{DBP}=$ diastolic blood pressure. Comparison between $\mathrm{Gl}$ and NG elderly subjects performed by $t$-student test. $p$ value $=$ statistical significance. 
(Figure 1A). The potential gender effect on diene formation in GI and NG groups was also analyzed. Figure $1 \mathrm{~B}$ shows that both men (reduction of $21 \%, \mathrm{p}<0.0168$ ) and women (reduction of $33 \%, \mathrm{p}<0.0311$ ) who drank guaraná showed a significant decrease in maximum CD production compared to their respective gender subjects that did not
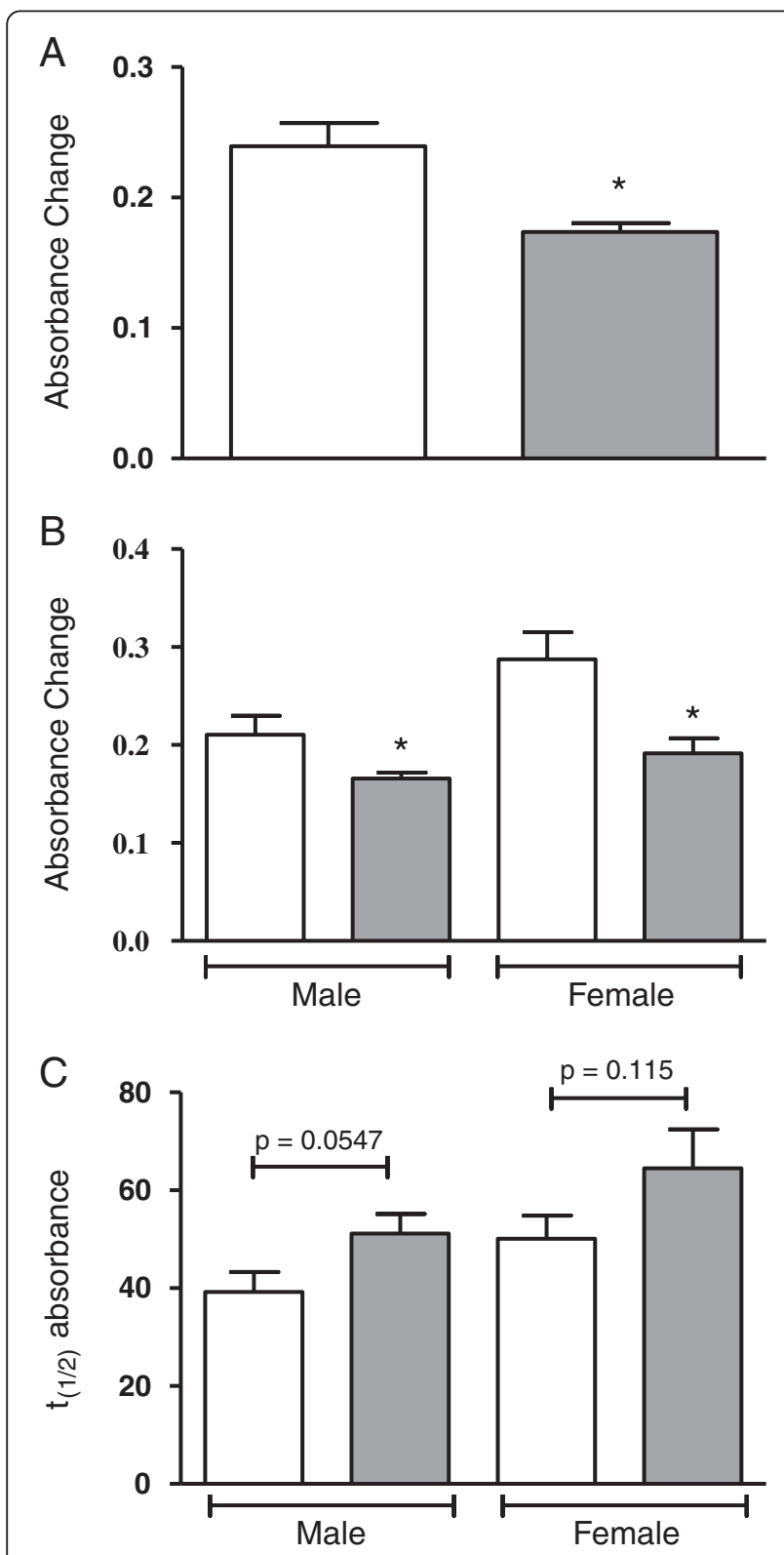

Figure 1 Maximum conjugated dienes production in serum from Maués inhabitants. Serum (diluted 100-fold) in PBS 10 mM (pH7.4) was incubated at $37^{\circ} \mathrm{C}$ for $180 \mathrm{~min}$ in the presence of $30 \mu \mathrm{M}$ $\mathrm{CuSO}_{4}$. Conjugated diene formation was measured by determining the absorbance at $245 \mathrm{~nm}$ every $20 \mathrm{~min}$. In panel A, maximum CD production in serum of $\mathrm{Gl}$ and NG subjects. In panel $\mathbf{B}$, gender effect on maximum CD production between $\mathrm{Gl}$ and NG groups. NG (white bars) and $\mathrm{Gl}$ (gray bars). In panel $\mathbf{C}$, the $\mathrm{t}_{(1 / 2)}$ indicates the time required to achieve $50 \%$ CD production.

* $p<0.05$ compared to white bar. drink guaraná. Figure $1 \mathrm{C}$ shows the time required to achieve $50 \% \mathrm{CD}$ production during $\mathrm{CuSO}_{4}$-induced serum oxidation. This result shows no significant difference between NG and GI groups. Pearson correlation tests were performed and there are no significant correlations between maximum conjugated dienes and either total cholesterol $(\mathrm{r}=0.188, \mathrm{p}=0.23)$ or LDL levels $(\mathrm{r}=0.137, \mathrm{p}=0.39)$. However, we found a significant correlation between total polyphenols and LDL levels in the GI group $(r=0.643$, $\mathrm{p}=0.007)$ but not in the NG group $(\mathrm{r}=0.197, \mathrm{p}=0.563)$.

\section{In vitro guaraná effect on LDL oxidation Conjugated diene $(C D)$ production}

Isolated LDL samples incubated with different concentrations of guaraná showed a concentration-dependent increase in the lag phase of LDL oxidation $\left(\mathrm{r}^{2}=0.88\right.$, $\mathrm{p}<0.001)$. Guaraná concentrations in the range of $0.5-$ $5 \mu \mathrm{g} / \mathrm{mL}$ significantly inhibited $\mathrm{CuSO}_{4}$-induced LDL oxidation, increasing the lag phase (Figure 2A). At concentrations of 1 and $5 \mu \mathrm{g} / \mathrm{mL}$, guaraná totally prevented LDL oxidation during an assay time of $180 \mathrm{~min}$ (Figure 2B). However, guaraná had no effect on the maximum rate of oxidation (data not shown).

\section{TBARS production}

LDL oxidation was also evaluated by TBARS formation. Figure 3 shows a significant effect of guaraná in preventing TBARS formation induced by $\mathrm{CuSO}_{4}$. The protective effect of guaraná was similar to that demonstrated in the $\mathrm{CD}$ experiments. Guaraná at $1 \mu \mathrm{g} / \mathrm{mL}$ showed a significant effect during an assay time of $60-180$ minutes. At a concentration of $5 \mu \mathrm{g} / \mathrm{mL}$, guaraná prevented TBARS formation during an assay time of $60-360 \mathrm{~min}$.

\section{LDL tryptophan fluorescence}

Figure 4 shows the time required to achieve 50\% Trp fluorescence $\left(t_{1 / 2}\right)$ during $\mathrm{CuSO}_{4}$-induced LDL oxidation. When compared to the control group, the presence of guaraná at all concentrations tested significantly increased the $t_{1 / 2}$ of Trp. Guaraná at 1 and $5 \mu \mathrm{g} / \mathrm{mL}$ showed a total protection during 180 minutes. This result was similar that for the conjugated dienes and TBARS formation.

\section{CD production in serum}

Serum oxidation was determined by $\mathrm{CD}$ formation at $245 \mathrm{~nm}$. No oxidation occurred in serum when the medium did not contain $\mathrm{CuSO}_{4}$. Figure 5 shows that guaraná at concentrations of 1 and $5 \mu \mathrm{g} / \mathrm{mL}$ was able to cause a significant increase in the lag phase of oxidation. At the highest concentration, guaraná totally inhibited the serum oxidation during the assay time. Similar to its effect on LDL oxidation, guaraná demonstrated no effect on the maximum oxidation rate in serum oxidation (data not shown). 


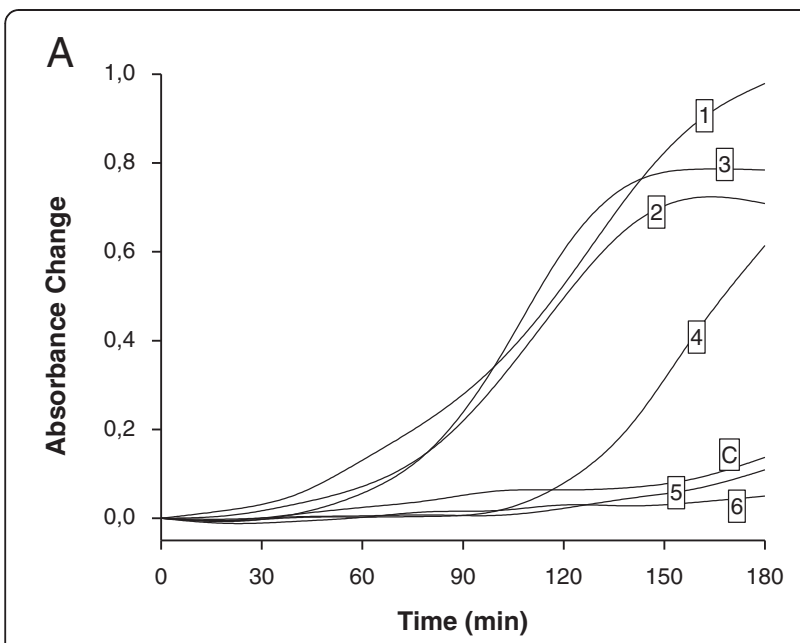

B

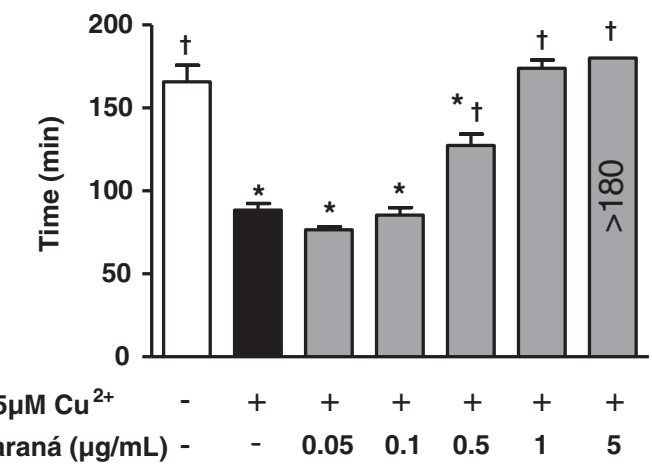

Figure 2 Effects of guaraná on LDL oxidation. LDL $(50 \mu \mathrm{g}$ protein/mL) was incubated in PBS $10 \mathrm{mM}\left(\mathrm{pH} \mathrm{7.4)}\right.$ at $37^{\circ} \mathrm{C}$ in the presence of $\mathrm{CuSO}_{4} 5 \mu \mathrm{M}$. Conjugated diene formation was measured by determining the absorbance at $234 \mathrm{~nm}$ every $20 \mathrm{~min}$. In panel $\mathbf{A}$, incubation medium did not contain guaraná (1) or contained $0.05 \mu \mathrm{g} / \mathrm{mL}$ (2), $0.1 \mu \mathrm{g} / \mathrm{mL}$ (3), $0.5 \mu \mathrm{g} / \mathrm{mL}$ (4), $1 \mu \mathrm{g} / \mathrm{mL}$ (5) or $5 \mu \mathrm{g} / \mathrm{mL}$ (6) of guaraná and control without $\mathrm{CuSO}_{4}$ and guaraná (C). In panel B the value of the lag phase determined graphically by the intercept of the tangents to the slow and fast increase of the diene absorption.

Experiments were repeated six times, showing similar results. ${ }^{*} p<0.05$ compared to group without $\mathrm{CuSO}_{4}$ and guaraná. $\dagger \mathrm{p}<0.05$ compared to group with $\mathrm{CuSO}_{4}$ and without guaraná.

\section{Total radical-trapping antioxidant potential of guaraná}

Figure 6 shows the antioxidant potential of guaraná when AAPH was used as pro-oxidant. This method is based on the use of a water-soluble azo compound, AAPH [2,20-azo-bis(2-amidinopropane)-dihydrochloride], as a reliable and quantifiable source of alkyl peroxyl radicals. The thermal decomposition of these compounds in the presence of luminol produces luminescence, which is quenched by the addition of peroxyl radical scavengers [15]. Guaraná concentrations ranging from 0.01 to $10 \mu \mathrm{g} / \mathrm{mL}$ were used in this experiment. We observed that all concentrations tested were able to reduce the AAPH-induced luminol oxidation, and that guaraná concentrations of $0.5-10 \mu \mathrm{g} / \mathrm{mL}$ demonstrated very strong inhibition.

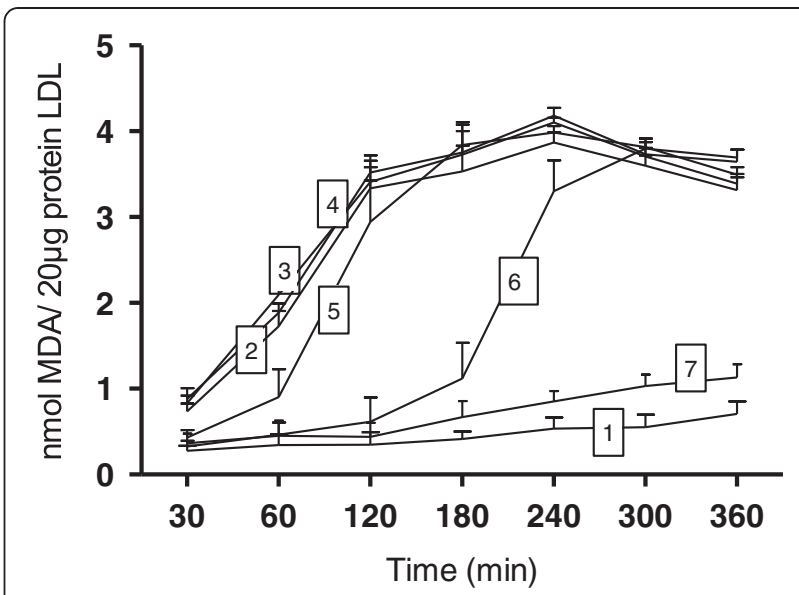

Figure 3 Effects of guaraná on thiobarbituric acid reactive substances (TBARS) production during $\mathrm{CuSO}_{4}$-induced LDL oxidation. LDL (50 $\mu \mathrm{g}$ protein/mL) was incubated in PBS $10 \mathrm{mM}$ ( $\mathrm{pH} 7.4$ ) at $37^{\circ} \mathrm{C}$ in the presence of $\mathrm{CuSO}_{4} 5 \mu \mathrm{M}$. Incubation medium did not contain guaraná and $\mathrm{CuSO}_{4}$ (1) or contained $\mathrm{CuSO}_{4}$ (2), $0.01 \mu \mathrm{g} / \mathrm{mL}$ (3), $0.05 \mu \mathrm{g} / \mathrm{mL}$ (4), $0.1 \mu \mathrm{g} / \mathrm{mL}$ (5), $1 \mu \mathrm{g} / \mathrm{mL}$ (6) or $5 \mu \mathrm{g} / \mathrm{mL}$ of guaraná. Experiments were repeated three times.

\section{Discussion}

To our knowledge, this is the first study conducted to investigate the potential association between guaraná effect on LDL and serum oxidation. The results showed that guaraná ingestion (GI) resulted in lower maximum conjugated diene production than that found in an elderly NG group (Figure 1). Furthermore, in vitro assays showed that guaraná increased the lag phase in the oxidation of LDL and serum in vitro (Figures 2 and 5), and also prevented TBARS production (Figure 3) and Trp destruction (Figure 4) in LDL oxidation. Moreover, we observed that guaraná extract demonstrates a peroxyl radical scavenger activity (Figure 6).

The effects of guaraná on LDL and serum oxidation are probably associated with some bioactive compounds (catechins and xantines) that are similar to those found in other foods, such as green tea [4]. Tea polyphenols are well studied and there are numerous studies consistently describing these compounds as having antioxidative, antithrombogenic, antiinflammatory, hypotensive, hypocholesterolemic, antihypertensive, and antiobesogenic effects [16]. The potential beneficial effects of daily guaraná consumption described by Krewer et al [11] include a lower prevalence of hypertension, obesity, and metabolic syndrome, and lower cholesterol (total and LDL) and AOPP levels in GI subjects. These effects are similar to those described in epidemiological studies involving green tea [17]. We believe that the results depicted here concerning the LDL oxidation could contribute in the elucidation of potential causal factors related to these associations.

First, it is important to consider the bioactive effects of guaraná related to the main chemical compounds. 




Figure 4 Effect of guaraná on Trp destruction in $\mathrm{CuSO}_{4}$-induced LDL oxidation. LDL ( $50 \mu \mathrm{g}$ protein/mL) was incubated in PBS with $5 \mu \mathrm{M}$ $\mathrm{CuSO}_{4}$ with different guaraná concentrations. Fluorescence $(\mathrm{Ex} / \mathrm{Em}=282 / 331 \mathrm{~nm})$ was measured at intervals of $20 \mathrm{~min}$ at $37^{\circ} \mathrm{C}$. The $\mathrm{t}_{(1 / 2)}$ means the time required for reaching half Trp fluorescence. Experiments were repeated three times, showing similar results. ${ }^{*} p<0.05$ compared to control with copper and without guaraná (black bar).

The antioxidant effects of guaraná extract might be due to methylxanthines, such as caffeine, theobromine, and theophylline, and also to tannins, saponins, catechins, epicatechins, proanthocyanidols, as well as trace concentrations of many other compounds [18]. Effect of caffeine on LDL resistance to oxidative modification has been excluded by several in vitro [19] and ex vivo [20] studies. Indeed, we tested the TRAP activity of caffeine and theobromine and we observed no effect for these two compounds (data not shown). On the other hand, caffeine has been linked to increased thermogenesis and

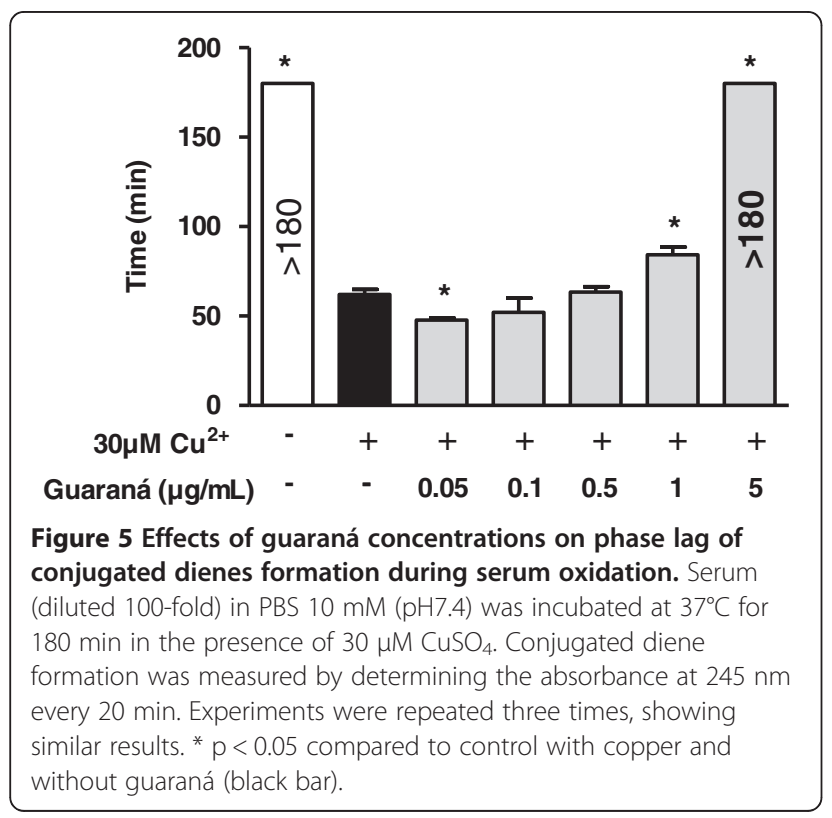

decreased body weight in some clinical studies [21]. These effects of caffeine may contribute to prevent the other risk factors related to atherosclerotic vascular disease such as waist circumference and blood pressure [11].

It has been shown that guaraná inhibits the lipid peroxidation process, an effect apparently associated with the high tannin content of the seeds, which reach concentrations between $16 \%$ and $31 \%$ [22,23]. Fresh tea leaf is unusually rich in the flavanol group of polyphenols

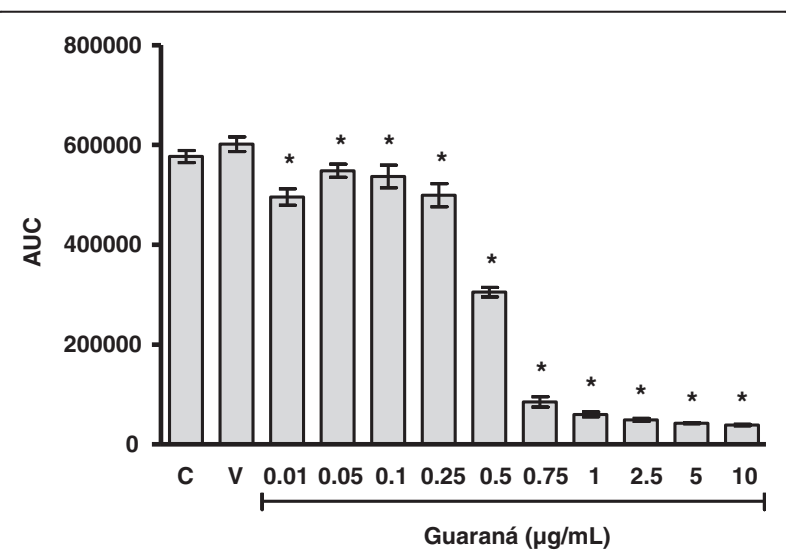

Figure 6 In vitro effect of guaraná on total radical-trapping antioxidant potential (TRAP). The reaction mixture contained $10 \mathrm{mM}$ AAPH, $35 \mu \mathrm{M}$ luminol and guaraná at different concentrations dissolved in $0.1 \mathrm{M}$ glycine buffer ( $\mathrm{pH}$ 8.6). The luminescence was measured every 5 minutes during 5 hours. The area under curve (AUC) was evaluated. (V) Vehicle and (C) Control. The bars represent mean \pm S.D. of five different experiments. ${ }^{*} p<$ 0.001 compared to control and vehicle group. There is no difference between vehicle and control group. 
known as catechins which may constitute up to $30 \%$ of the dry leaf weight and there is no tannic acid in tea [24]. Tannins are polyphenolic compounds having molecular masses between 500 and $3000 \mathrm{Da}$ and a sufficiently large number of phenolic groups [25]. Yamaguti-Sasaki et al. [22] identified some procyanidins (condensed tannins) as epicatechin-( $4 \beta \rightarrow 8)$-epicatechin (procyanidin B2), catechin- $(4 \alpha \rightarrow 8)$-catechin (procyanidin B3), and catechin-( $4 \alpha \rightarrow 8)$-epicatechin (procyanidin B4). It has been demonstrated that green tea catechins demonstrate antioxidant activity by scavenging free radicals and chelating redox active transition-metal ions [26]. Catechins have many phenolic hydroxyl groups in their structures and have been shown to inhibit oxidative modification of LDL when added before initiation of oxidation [27]. However, the mechanisms by which these flavonoids inhibit LDL oxidation have not been clarified. Because of their amphipathic nature, flavonoids may act within the LDL particle in a manner similar to that of vitamin E, or may act in a manner comparable with that of ascorbic acid in the extraparticle environment of LDL. Considering our in vivo results (Figure 1) and the significant correlation between the total polyphenols and the LDL levels in the GI group, we may suppose that polyphenols from guaraná could incorporate into LDL, turning the serum from GI subjects less susceptible to oxidation in vitro.

Guaranás effect on lipid peroxidation in vitro is in agreement with Mattei et al [23], who showed that guaraná extract inhibited lipoperoxidation even at low concentrations $(1.2 \mu \mathrm{g} / \mathrm{mL})$. Besides their in vitro effects, catechins demonstrate additional effects in vivo by inhibiting redox active transcriptional factors, inhibiting pro-oxidant enzymes, and inducing antioxidant enzymes, which could explain their beneficial effects in vivo [26]. These effects make the potential use of guaraná extract even most promising to promote protection against atherogenesis.

In our in vivo study, the diene levels were significantly lower in GI than in NG subjects. It may indicate that guaraná intake is able to provide an additional antioxidant protection to serum and, mainly, to LDL. It was in agree with our in vitro data, which could increase the lag phase of serum and LDL oxidation, prevent TBARS production and tryptophan destruction (Figures 2, 3, 4 and 5). However, the time required to achieve 50\% CD production was not significant different. We believe that it was not significant because of the low number of subjects. In the actual in vivo condition, the polyphenols and methylxanthines in plasma may work together to prevent LDL oxidation. These polyphenols may be more easily incorporated into LDL in vivo than in vitro. Although guaraná polyphenols may be metabolized quickly after entering the circulation, it is possible that these metabolites also exert preventive effects on LDL oxidation. Repeated exposure of LDL particles to guaraná polyphenols over a long period of time may enrich the LDL particles sufficiently to make them less susceptible to oxidative stress.

It is important to ponder some considerations associated with the methodological design of our in vivo protocol. Since the in vivo study was performed using a group of elderly subjects, and without controlling for the amounts of guaraná ingested or the ingestion of other foods rich in antioxidants or bioactive compounds, it is important to conduct additional controlled studies on the possible effect of guaraná ingestion on LDL oxidation levels to confirm the results described here.

\section{Conclusion}

In summary, in vivo results showed that guaraná intake could reduce the diene levels in serum from elderly subject. This positive effect of guaraná could be confirmed by in vitro results which showed an increased resistance to LDL oxidation. It was due to high content of polyphenolic compounds, which may act to prevent atherogenesis through a combination of effects, including the other positive effects of guaraná on lipid metabolism [7], in body weight loss [8], and increases basal energy expenditure [9], besides the lower prevalence of hypertension, metabolic syndrome, and lower cholesterol and AOPP levels in GI subjects [11]. Considering these results, our study indicates that consumption of guaraná regularly or its possible inclusion in diet-based therapies could yield certain health benefits and potential defense against oxidative stress and metabolic disorders.

\section{Materials and methods}

\section{In vivo assay: effect of habitual guaraná consumption on serum oxidation}

The elderly patients were classified into two groups based on self-reported data: those who habitually ingested guaraná (at least 5 times a week; GI) and those who never ingested guaraná (NG). From a previous data and biological bank of the study performed by Krewer et al [11] that investigated elderly included in GI $(n=421)$ and NG groups (NG, $\mathrm{n}=239$ ) we select 42 samples from 22 males and 20 females ( $\geq 60$ years of age, 23 GI and 19 NG) to perform a serum oxidation analysis. We selected subjects without previous life style as smoking habit and higher alcoholic beverage consumption and without morbidities that could to influence the analysis of serum oxidation as: type 2 diabetes mellitus, obesity, dyslipidemia, severe hypertension, metabolic syndrome, cardiovascular diseases, neoplasias and other metabolic diseases. The methodology used to determine biochemical parameters from elderly Riverine inhabitants who habitually ingest guaraná (GI) and those who never ingest guaraná (NG) are described in materials and methods from Krewer et al [11]. 
The Maués elderly population study was approved by the Ethical Committee of the Universidade do Estado do Amazonas, Brasil ( $\left.n^{\circ} 807 / 04\right)$. Since the vast majority of the elderly included in this study were illiterate, oral consent or fingerprint in Term was obtained to indicate their voluntary participation in the study after the researchers read the consent form to the patients.

Venous blood was drawn from these 42 previous selected elderly subjects into tubes containing no anticoagulant and centrifuged at $1000 \mathrm{~g}$ for $15 \mathrm{~min}$ and the serum was stored at $-20^{\circ} \mathrm{C}$ until to be analyzed. Serum diluted 100 -fold was incubated at $37^{\circ} \mathrm{C}$ in a medium containing $10 \mathrm{mM}$ phosphate buffer ( $\mathrm{pH}$ 7.4). The oxidation was initiated by the addition of $\mathrm{CuSO}_{4}(30 \mu \mathrm{M}$, final concentration) and conjugated dienes (CD) formation was monitored at $245 \mathrm{~nm}$ as previously described [28].

\section{Guaraná extract}

Powdered Paullinia cupana Kunth seed produced and supplied by EMBRAPA Oriental (Agropecuary Research Brazillian Enterprise) located Western Amazon in Maués, Amazonas-Brazil was used in all experiments. The guaraná powder was conserved in dry conditions at $\pm 4^{\circ} \mathrm{C}$, protected against light action until the extracts preparations.

We used a hydro-alcoholic extract of Paullinia cupana Kunth using alcohol and water (70:30) to $100 \mathrm{~mL}$ of extraction fluid prepared at a concentration of $300 \mathrm{mg} / \mathrm{mL}$. The detailed description and determination of mainly bioactive compounds presents guaraná extract used in this study is presented in Bittencourt et al (Bittencourt LS, Machado DC, Machado MM, Santos GFF, Algarve TD, Marinowic DR, Ribeiro EE, Soares FAA, Athayde ML, Cruz IBM, unpublished data, 2011). Briefly, after 21 days of guaraná extraction the extract was centrifuged for $1000 \mathrm{~g}$ during $10 \mathrm{~min}$ and the supernatant was isolated and lyophilized. The mainly xanthines and catechins presented in guaraná extract were analyzed by chromatography and from this analysis was found caffeine $=12.240 \mathrm{mg} / \mathrm{g}$, theobromine $=6.733 \mathrm{mg} / \mathrm{g}$, total catechins $=4.336 \mathrm{mg} / \mathrm{g}$, and condensed tannins $=22 \mathrm{mg} / \mathrm{g}$.

The guaraná solution used in the study was prepared based on Santa Maria et al [29] protocol. The extract obtained and lyophilized was diluted in distillated water prepared at a concentration of $200 \mathrm{mg} / \mathrm{mL}$. The mixture was infused for $7 \mathrm{~min}$ in boiling, and centrifuged (600 g, $15 \mathrm{~min}$ ) and filtered. Five guaraná concentrations were tested here: $0.05,0.1,0.5,1$ and $5 \mu \mathrm{g} / \mathrm{mL}$. In TRAP assay were used different guaraná concentrations (0.01-10 $\mu \mathrm{g} / \mathrm{mL})$.

\section{LDL isolation to in vitro protocol tests}

To perform in vitro LDL-oxidation assays in the presence of guaraná, firstly the LDL was isolated from fresh human plasma by discontinuous density-gradient ultracentrifugation as described by Silva et al [30], with few modifications. Briefly, plasma of three healthy normolipidemic voluntary donors that did not ingest guaraná in their habitual diet collected with EDTA $(1 \mathrm{mg} / \mathrm{mL})$ was pooled and sucrose (final concentration, $0.5 \%$ ) was added to prevent LDL aggregation. Five milliliters of EDTAplasma adjusted to a density of $1.22 \mathrm{~g} / \mathrm{mL}$ with solid $\mathrm{KBr}$ $(0.326 \mathrm{~g} / \mathrm{mL})$ was layered on the bottom of a centrifuge tube. Then, $5 \mathrm{~mL}$ EDTA-containing sodium chloride solution (density $1.006 \mathrm{~g} / \mathrm{mL}$ ) was overlaid on the top of the plasma. Ultracentrifugation was run at 350,000 g for $2 \mathrm{~h}$ at $4^{\circ} \mathrm{C}$, in a Himac CP80MX ultracentrifuge. LDL particles were collected by the aspiration of the yellow/orange band at the middle of the saline layer and dialyzed exhaustively overnight at $4^{\circ} \mathrm{C}$ with $10 \mathrm{mM}$ phosphate buffer ( $\left.\mathrm{pH} 7.4\right)$. Protein concentration in LDL solution was determined by Lowry's method [31]. The purity of LDL preparation was verified by agarose gel electrophoresis. Isolated LDL was stored at $-20^{\circ} \mathrm{C}$ for no longer than 2 weeks.

\section{In vitro $\mathrm{LDL}$ oxidation analysis \\ Conjugated dienes and TBARS formation}

LDL samples $(50 \mu \mathrm{g}$ protein $/ \mathrm{mL})$ were pre-incubated at $37^{\circ} \mathrm{C}$ in a medium containing $10 \mathrm{mM}$ phosphate buffer $(\mathrm{pH} 7.4)$ and different guaraná concentrations (0.05 $5 \mu \mathrm{g} / \mathrm{mL})$. After 5 minutes, the oxidation was initiated by the addition of $\mathrm{CuSO}_{4}(5 \mu \mathrm{M}$, final concentration). The oxidation was monitored by measuring the increase in absorbance at $234 \mathrm{~nm}$ due to conjugated diene (CD) formation as previously described [32]. Aliquots were also removed at different time points for evaluating thiobarbituric acid reactive substances (TBARS) production as previously described [33].

\section{Measurement of LDL- Tryptophan fluorescence}

The fluorescence spectra of native LDL display a single band centered at approximately $332 \mathrm{~nm}$, which is assigned to the tryptophan (Trp) residues in apolipoprotein B-100 (apoB-100) [34]. Loss of Trp fluorescence is a marker for oxidations at the protein core of LDL [34]. Trp fluorescence was measured in a solution of LDL $(50 \mu \mathrm{g}$ protein $/ \mathrm{mL})$ in PBS $(10 \mathrm{mM}) \mathrm{pH} 7.4$ at $37^{\circ} \mathrm{C}$, using a Shimatzo espectrofluorometer (excitation at $282 \mathrm{~nm}$ and emission at $331 \mathrm{~nm}$ ) [34]. The kinetics of LDL oxidation was followed by measuring the decrease of Trp-fluorescence, corresponding to the decomposition of this amino acid, after the addition of $\mathrm{CuSO}_{4}(5 \mu \mathrm{M}$, final concentration), in absence or presence of guaraná $(0.05-5 \mu \mathrm{g} / \mathrm{mL})$. The cuvettes had to be removed from the excitation light between the single measurements to avoid photooxidation of the Trp residues; fluorescence was measured every $20 \mathrm{~min}$. Data are shown as the percent decrease of Trp fluorescence in each sample. The time required for reaching half Trp fluorescence $\left(t_{1 / 2}\right)$ was calculated. 


\section{In vitro serum oxidation}

Venous blood was drawn from nonfasted healthy normolipidemic voluntary donors into tubes containing no anticoagulant and centrifuged at $1000 \mathrm{~g}$ for $15 \mathrm{~min}$. Serum diluted 100 -fold was incubated at $37^{\circ} \mathrm{C}$ in a medium containing $10 \mathrm{mM}$ phosphate buffer $(\mathrm{pH} 7.4)$ and different guaraná concentrations $(0.05-5 \mu \mathrm{g} / \mathrm{mL})$. The oxidation was initiated by the addition of $\mathrm{CuSO}_{4}(30 \mu \mathrm{M})$ and $\mathrm{CD}$ formation was monitored at $245 \mathrm{~nm}$ as previously described [28].

\section{Determination of lag phase and maximum oxidation rate} In the studies of $\mathrm{CD}$ formation, there are several parameters which can be obtained from diene vs. time profiles. The value of the lag phase is commonly determined graphically by the intercept of the tangents to the slow and fast increase of the diene absorption. Another parameter is the maximum oxidation rate, given by the peak of the first derivative, i.e. change of $\mathrm{A}_{234}$ as a function of time [32].

\section{Total radical-trapping antioxidant potential (TRAP)}

TRAP was determined by measuring the chemiluminescence intensity of luminol induced by [2,20-azo-bis(2amidinopropane)-dihydrochloride] (AAPH) thermolysis in a luminometer BioTek Synergy 2 [15]. The reaction mixture contained AAPH $(10 \mathrm{mM})$ and luminol $(35 \mu \mathrm{M})$ dissolved in $0.1 \mathrm{M}$ glycine buffer ( $\mathrm{pH}$ 8.6). Incubation of this mixture generates an almost constant light intensity at room temperature after stabilization. Guaraná was added in different concentrations to determine the TRAP activity. At this point, the luminescence intensity is practically abolished. In the course of time, with the loss of antioxidant capacity of guaraná, the luminescence intensity returns to the initial values. The area under curve (AUC) was evaluated for each guaraná concentration and compared to vehicle AUC [15].

\section{Statistical analysis}

Statistical analysis was performed using the SPSS statistical package, version 17.0 (SPSS, Inc., IL). Data are expressed as means $\pm \mathrm{SD}$. Comparison between characteristics baselines and serum oxidation of GI and NG elderly subjects was performed by Student $t$-test. Multivariate logistic regression (Backward Wald method) and Pearson correlation tests were performed to observe possible intervenient factors. In vitro LDL-oxidation assays were statistically analyzed using a one-way analysis of variance (ANOVA), followed by Student-Newman-Keuls test when appropriate. In addition, linear regression was performed to identify a possible dose dependent effect. Values of $\mathrm{p}<0.05$ were considered significant.

\footnotetext{
Abbreviations

AAPH: 2,21-Azobis(2-methylpropionamidine) dihydrochloride;

AOPP: Advanced oxidative protein product; apoB-100: Apolipoprotein B-100; AUC: Area under curve; CD: Conjugated diene; CHD: Coronary heart disease;
}

FDA: Food and Drug Administration; Gl: Guaraná intake; NG: No guaraná intake; LDL: Low density lipoprotein; HDL: High-density lipoprotein; MDA: Malondialdehyde; PUFA: Polyunsaturated fatty acid; TBARS: Thiobarbituric acid reactive substances; TRAP: Total radical-trapping antioxidant potential; Trp: Tryptophan; VLDL: Very low density lipoprotein.

\section{Competing interests}

The authors declare that they have no competing interests.

\section{Authors' contributions}

The authors' responsibilities were as follows: RLP was involved in data collection, data analysis, data interpretation, literature search and manuscript preparation; RPB, EJFR, EER and LS were involved in data collection, data analysis and data interpretation; IBMC and F.A.A.S. were involved in the study design, data interpretation and review of the manuscript; all authors contributed to the revision of the manuscript and final approval of the manuscript

\section{Acknowledgments}

We are grateful to the Maués governmental team and to Amazonas Governmental Health Service (ESF-SUS) and the all research team that assisted in data and blood sample collection. We are grateful to BioMed Proofreading. This work was supported by the "Financiadora de Estudos e Projetos" (FINEP) research grant "Rede Instituto Brasileiro de Neurociência (IBN-Net)" \# 01.06.0842-00 and "Instituto Nacional de Ciência e Tecnologia" (INCT) for Excitotoxicity and Neuroprotection- MCT/CNPq, "Coordenação de Aperfeiçoamento de Pessoal de Nível Superior" (CAPES), "Fundação de Amparo à Pesquisa do Estado do Amazonas" (FAPEAM) and "Conselho Nacional de Desenvolvimento Científico e Tecnológico" (CNPq).

\section{Author details}

1Departamento de Química, Centro de Ciências Naturais e Exatas, Universidade Federal de Santa Maria, Campus UFSM, Santa Maria, RS, Brazil. ${ }^{2}$ Universidade Aberta da Terceira Idade, Universidade do Estado do Amazonas, Amazonas, Brazil. ${ }^{3}$ Departamento de Morfologia, Centro de Ciências da Saúde, Universidade Federal de Santa Maria, Campus UFSM, Santa Maria, RS, Brazil.

\section{Received: 23 October 2012 Accepted: 31 January 2013}

Published: 8 February 2013

\section{References}

1. Hodgson JM, Croft KD: Tea flavonoids and cardiovascular health. $\mathrm{Mol}$ Aspects Med 2010, 31:495-502.

2. de Koning Gans JM, Uiterwaal CS, van der Schouw YT, Boer JM, Grobbee DE, Verschuren WM, Beulens JW: Tea and coffee consumption and cardiovascular morbidity and mortality. Arterioscler Thromb Vasc Biol 2010, 30:1665-1671.

3. Heckman MA, Weil J, Gonzales de Mejia E: Caffeine (1, 3, 7trimethylxanthine) in foods: a comprehensive review on consumption, functionality, safety, and regulatory matters. J Food Sci 2010, 75:R77-R87.

4. Angelo PC, Nunes-Silva CG, Brigido MM, Azevedo JS, Assuncao EN, Sousa AR, Patricio FJ, Rego MM, Peixoto JC, Oliveira WP Jr, et al: Guarana (Paullinia cupana var. sorbilis), an anciently consumed stimulant from the Amazon rain forest: the seeded-fruit transcriptome. Plant Cell Rep 2008, 27:117-124.

5. Smith N, Atroch AL: Guarana's Journey from regional tonic to aphrodisiac and global energy drink. Evid Based Complement Alternat Med 2010, 7:279-282.

6. Duchan E, Patel ND, Feucht C: Energy drinks: a review of use and safety for athletes. Phys Sportsmed 2010, 38:171-179.

7. Lima WP, Carnevali LC Jr, Eder R, Costa Rosa LF, Bacchi EM, Seelaender MC Lipid metabolism in trained rats: effect of guarana (Paullinia cupana Mart.) supplementation. Clin Nutr 2005, 24:1019-1028.

8. Boozer CN, Nasser JA, Heymsfield SB, Wang V, Chen G, Solomon JL: An herbal supplement containing Ma Huang-Guarana for weight loss: a randomized, double-blind trial. Int J Obes Relat Metab Disord 2001, 25:316-324.

9. Berube-Parent S, Pelletier C, Dore J, Tremblay A: Effects of encapsulated green tea and Guarana extracts containing a mixture of epigallocatechin-3-gallate and caffeine on $24 \mathrm{~h}$ energy expenditure and fat oxidation in men. Br J Nutr 2005, 94:432-436.

10. Bydlowski SP, Yunker RL, Subbiah MT: A novel property of an aqueous guarana extract (Paullinia cupana): inhibition of platelet aggregation in vitro and in vivo. Braz J Med Biol Res 1988, 21:535-538. 
11. Costa Krewer C, Ribeiro EE, Ribeiro EA, Moresco RN, Ugalde Marques da Rocha MI, Santos Montagner GF, Machado MM, Viegas K, Brito E, Cruz IB: Habitual intake of guarana and metabolic morbidities: an epidemiological study of an elderly amazonian population. Phytother Res 2011, 25:1367-1374.

12. Niki E: Do free radicals play causal role in atherosclerosis? Low density lipoprotein oxidation and vitamin E revisited. J Clin Biochem Nutr 2011, 48:3-7.

13. Bruckdorfer KR: Antioxidants and CVD. Proc Nutr Soc 2008, 67:214-222.

14. Mehmetcik G, Ozdemirler G, Kanbagli O, Toker G, Uysal M: Age-related changes in plasma lipid peroxidation and antioxidant system in humans and rats. Arch Gerontol Geriatr 1997, 25:305-310.

15. Dresch MT, Rossato SB, Kappel VD, Biegelmeyer R, Hoff ML, Mayorga P, Zuanazzi JA, Henriques AT, Moreira JC: Optimization and validation of an alternative method to evaluate total reactive antioxidant potential. Anal Biochem 2009, 385:107-114.

16. Yung LM, Leung FP, Wong WT, Tian XY, Yung LH, Chen ZY, Yao XQ, Huang $Y$ : Tea polyphenols benefit vascular function. Inflammopharmacology 2008, 16:230-234.

17. Chacko SM, Thambi PT, Kuttan R, Nishigaki I: Beneficial effects of green tea: a literature review. Chin Med 2010, 5:13.

18. Belliardo F, Martelli A, Valle MG: HPLC determination of caffeine and theophylline in Paullinia cupana Kunth (guarana) and Cola spp. samples. Z Lebensm Unters Forsch 1985, 180:398-401.

19. Krisko A, Kveder M, Pifat G: Effect of caffeine on oxidation susceptibility of human plasma low density lipoproteins. Clin Chim Acta 2005, 355:47-53.

20. Hodgson JM, Puddey IB, Croft KD, Burke V, Mori TA, Caccetta RA, Beilin LJ: Acute effects of ingestion of black and green tea on lipoprotein oxidation. Am J Clin Nutr 2000, 71:1103-1107.

21. Westerterp-Plantenga MS: Green tea catechins, caffeine and body-weight regulation. Physiol Behav 2010, 100:42-46.

22. Yamaguti-Sasaki E, Ito LA, Canteli VC, Ushirobira TM, Ueda-Nakamura T, Dias Filho BP, Nakamura CV, de Mello JC: Antioxidant capacity and in vitro prevention of dental plaque formation by extracts and condensed tannins of Paullinia cupana. Molecules 2007, 12:1950-1963.

23. Mattei R, Dias RF, Espinola EB, Carlini EA, Barros SB: Guarana (Paullinia cupana): toxic behavioral effects in laboratory animals and antioxidants activity in vitro. J Ethnopharmacol 1998, 60:111-116

24. Graham HN: Green tea composition, consumption, and polyphenol chemistry. Prev Med 1992, 21:334-350.

25. Quideau S, Deffieux D, Douat-Casassus C, Pouysegu L: Plant polyphenols: chemical properties, biological activities, and synthesis. Angew Chem Int Ed Eng/ 2011, 50(3):586-621.

26. Babu PV, Liu D: Green tea catechins and cardiovascular health: an update. Curr Med Chem 2008, 15:1840-1850.

27. Miura S, Watanabe J, Sano M, Tomita T, Osawa T, Hara Y, Tomita I: Effects of various natural antioxidants on the $\mathrm{Cu}(2+)$-mediated oxidative modification of low density lipoprotein. Biol Pharm Bull 1995, 18:1-4.

28. Schnitzer E, Pinchuk I, Bor A, Fainaru M, Samuni AM, Lichtenberg D: Lipid oxidation in unfractionated serum and plasma. Chem Phys Lipids 1998, 92:151-170.

29. Santa Maria A, Lopez A, Diaz MM, Munoz-Mingarro D, Pozuelo JM: Evaluation of the toxicity of guarana with in vitro bioassays. Ecotoxicol Environ Saf 1998, 39:164-167.

30. Luiz da Silva E, Tsushida T, Terao J: Inhibition of mammalian 15-lipoxygenasedependent lipid peroxidation in low-density lipoprotein by quercetin and quercetin monoglucosides. Arch Biochem Biophys 1998, 349:313-320.

31. Lowry OH, Rosebrough NJ, Farr AL, Randall RJ: Protein measurement with the Folin phenol reagent. J Biol Chem 1951, 193:265-275.

32. Gieseg SP, Esterbauer H: Low density lipoprotein is saturable by prooxidant copper. FEBS Lett 1994, 343:188-194.

33. Ohkawa $H$, Ohishi $N$, Yagi K: Assay for lipid peroxides in animal tissues by thiobarbituric acid reaction. Anal Biochem 1979, 95:351-358.

34. Giessauf A, Steiner E, Esterbauer H: Early destruction of tryptophan residues of apolipoprotein $B$ is a vitamin E-independent process during coppermediated oxidation of LDL. Biochim Biophys Acta 1995, 1256:221-232.

\section{Submit your next manuscript to BioMed Central and take full advantage of:}

- Convenient online submission

- Thorough peer review

- No space constraints or color figure charges

- Immediate publication on acceptance

- Inclusion in PubMed, CAS, Scopus and Google Scholar

- Research which is freely available for redistribution 